\title{
Stable individual variation in ventral spotting patterns in Phyllomedusa trinitatis (Anura: Phyllomedusidae) and other Phyllomedusa species: a minimally invasive method for recognizing individuals
}

\author{
Joanna M. Smith, ${ }^{1}$ Adam Bland, ${ }^{2}$ Eleanor Gourevitch, ${ }^{3}$ Paul A. Hoskisson, ${ }^{4}$ and J. Roger Downie ${ }^{3}$ \\ ${ }^{1}$ School of Biological Sciences, University of Bangor. Bangor, Gwynedd, LL57 2DG, UK. E-mail: j.smith@bangor.ac.uk. \\ ${ }^{2}$ Chester Zoo. Moston Road, Upton-by Chester, Upton, Chester CH2 1EU, UK. E-mail: A.Bland@chesterzoo.org. \\ ${ }^{3}$ School of Life Sciences, Graham Kerr Building, University of Glasgow. Glasgow G12 8QQ, UK. E-mail: roger.downie@ \\ glasgow.ac.uk. \\ ${ }^{4}$ Strathclyde Institute of Pharmacy and Biomedical Sciences, University of Strathclyde. 161 Cathedral Street, Glasgow G4 \\ ORE, UK.
}

\begin{abstract}
Stable individual variation in ventral spotting patterns in Phyllomedusa trinitatis (Anura: Phyllomedusidae) and other Phyllomedusa species: a minimally invasive method for recognizing individuals. We describe a distinctive pattern of individually variable white 'islands' and dots on the ventral surfaces of the throat and forearm regions of male and female Phyllomedusa trinitatis. Crucially, we report from captive-reared individuals that these patterns are ontogenetically stable. We have used these patterns to recognize individual frogs in populations of 60 and more. Examination of the ventral surfaces of other Phyllomedusa species in museum specimens and from published accounts suggests that use of these patterns provides a generally useful, minimally invasive recognition method in this genus. We find that species previously classed as Phyllomedusa but now regarded as belonging to different genera lack these patterns.
\end{abstract}

Keywords: individual recognition, Trinidad Leaf Frogs, ventral patterns.

\section{Resumo}

Variação individual estável no padrão de manchas ventrais em Phyllomedusa trinitatis (Anura: Phyllomedusidae) e em outras espécies de Phyllomedusa: um método minimamente invasivo para o reconhecimento de indivíduos. Descrevemos aqui um padrão distintivo de "ilhas" e pontos brancos individualmente variáveis nas superfícies ventrais das regiões da garganta e do antebraço de machos e fêmeas de Phyllomedusa trinitatis. Crucialmente, a partir de indivíduos criados em cativeiro relatamos que esses padrões são ontogeneticamente estáveis. Usamos esses

Received 26 November 2018

Accepted 14 May 2019

Distributed June 2019 
padrões para reconhecer pererecas individuais em populações de 60 ou mais indivíduos. O exame das superfícies ventrais de outras espécies de Phyllomedusa em espécimes de museus e de relatos publicados sugere que o uso desses padrões fornece um método de reconhecimento minimamente invasivo e geralmente útil nesse gênero. Descobrimos que espécies anteriormente classificadas como Phyllomedusa, mas agora consideradas pertencentes a diferentes gêneros, não possuem esses padrões.

Palavras-chave: padrões ventrais, pererecas-folhas-de-trinidad, reconhecimento individual.

\section{Introduction}

Many field studies in animal ecology, such as population estimations via mark-recapture methods, life history analysis and the understanding of interactions in social behavior require the reliable long-term recognition of individuals. In many amphibian species, this is made difficult by uniform markings that generally vary little between individuals and because most have moist, sheddable and permeable skin that takes dye marks poorly. Ferner (2010), when reviewing available methods for marking amphibians, concluded that for adult anurans 'toe-clipping remains the method of choice', though the use of passive integrated transponders (PIT) and visible implant elastomer (VIE) marking has significant potential, where finances allow (Heard et al. 2008, Sapsford et al. 2015). However, it seems that PIT tags and VIE can have limited retention and detection rates in adult frogs (Brannelly et al. 2013, 2014, Bainbridge et al. 2015). Furthermore, several studies suggest that the effects of invasive marking techniques can influence the expression of natural behaviors in amphibians, such as courtship (Winandy and Denoël 2011), feeding ability (Davis and Ovaska 2001) and locomotory performance (Schmidt and Schwarzkopf 2010).

Evidence about the effects on survival and stress following toe-clipping in frogs is variable and contested (Narayan et al. 2011, Fisher et al. 2013). Even studies that suggest toe-clipping has minimal effects on survival advise due consideration of 'functionally important' digits and restraint in numbers of toes clipped (Grafe et al. 2011), particularly given that return rates in mark-recapture studies fall drastically with each toe clipped (McCarthy and Parris 2004). Toeclipping seems especially problematic for frogs with adhesive toe-pads since these cannot be regenerated and are critical to the animals' way of life. Following discussions of the ethical justifiability of toe-clipping in the light of such findings (May 2004, Parris et al. 2010), herpetologists are keen to find viable alternatives that provide similar rates of recognition and return as toe-clipping (BHS 2017).

Ferner (2010) also recommended the consideration of non-invasive techniques such as the use of individual pattern differences where these exist. Individual pattern recognition is made much more feasible by the advent of digital photography where large numbers of photographs can be easily, cheaply and quickly taken and the bank of photographs can be quickly scanned on a computer screen. Ideally, what is needed is an individually recognizable pattern difference that can quickly be distinguished and is stable over time. In great crested newts, Triturus cristatus (Laurenti, 1768), belly patterns are complex and variable and can be used for individual recognition (Hagström 1973) but ontogenetic pattern variation does occur (Arntzen and Teunis 1993) and the complexity of the patterns makes individual recognition tedious and time-consuming when populations are large (McNeill, pers. comm.). In their study of PITtagging compared to pattern mapping Arntzen et al. (2004) suggested that non-invasive pattern mapping 'by eye' is only more cost-effective where populations have fewer than 176 individuals. However, with increasing availability of image analysis software, and the development of 
specific pattern-matching programs for use in wildlife studies, the potential for using photographic evidence to study large populations of animals is now far greater than it was, even a decade ago (Mettouris et al. 2016).

Here we present evidence on a reliable, stable, individually variable pattern occurring in at least some members of the neotropical genus Phyllomedusa (Anura: Phyllomedusidae). Phyllomedusa currently comprises 16 species (Frost 2018). Formerly, most of the species could be assigned to one of four species groups: $P$. tarsius, $P$. burmeisteri, $P$. hypochondrialis, and $P$. perinesos. Following the taxonomic revision by Duellman et al. (2016), members of the $P$. hypochondrialis Group were assigned to the genus Pithecopus and $P$. perinesos Group to Callimedusa, leaving $P$. tarsius Group and P. burmeisteri Group species within Phyllomedusa. In a non refereed report, one of us (JMS in Smith et al. 2007) presented evidence that the variable ventral markings found on Phyllomedusa trinitatis Mertens, 1926 skin could be used to recognize individuals. Here, we describe the ventral pattern as found in this species, provide evidence on its ontogenetic stability and its usefulness in a field study in Trinidad, West Indies, and describe similar patterns found in some other members of the genus.

\section{Materials and Methods}

\section{Field Observations and Egg Collections}

In July-August 2006, a population of Phyllomedusa trinitatis was monitored over six separate nights at a flooded roadside ditch on the Valencia-Matura Road (9.75 km marker) in Trinidad, West Indies. On each night, frogs were captured by hand, weighed using a spring balance, and their ventral surfaces were photographed using a digital camera. Individuals of this species are easy to capture since they are slow-moving and tend not to attempt to jump away when caught.
In 2014, 2015 and 2016, a population of $P$. trinitatis was observed around a set of artificial ponds at the William Beebe Research Station ('Simla') in Trinidad's Arima Valley (Downie et al. 2013) during the early months of the rainy season (June-August). Frogs were located at night by call and movement in the trees and bushes overhanging the ponds. Frogs were captured, measured and photographed as above. It was sometimes possible to photograph the ventral markings without capturing the frog, thereby reducing any stress related to handling. Sex was determined by size and behavior [females are significantly larger (90 mm SVL) than males (80 mm): Murphy 1997]. Each frog was assigned a unique number and location (there are three different pond sites) and then released where captured. Sampling was repeated multiple times in each of the years (nightly in 2016; less frequently in 2014 and 2015, usually on nights following wet days). Full measurements and photographs were taken each time and later checked visually against our accumulating photograph database to determine which of the frogs had been previously recorded and which were new. It took about $10 \mathrm{~min}$ to check five new photographs. Size measurements were used as a double check on identification. One experienced observer (E.G.) both photographed the frogs and checked the database. Using one experienced observer for this task made it less time consuming as the database accumulated.

Two freshly-laid egg clutches (300-400 eggs in each), wrapped in leaves, were collected in July 2014 from branches overhanging the ponds at Simla in the mornings following wet days. These clutches were incubated on moist paper in polythene containers and transported to our laboratory in the University of Glasgow in time for hatching, which takes about seven days after oviposition (Downie et al. 2013).

\section{Tadpole and Frog Rearing}

Collected egg clutches were suspended above tanks of dechlorinated, copper-free aerated tap 
water in a room kept at $23-25^{\circ} \mathrm{C}$ with a $12 / 12 \mathrm{~h}$ light regime in our Glasgow laboratory. Once hatchlings entered the water, they were subdivided into batches of about 40 per $40 \times 20 \mathrm{~cm}$ tank, in water $20 \mathrm{~cm}$ deep. Tadpoles were fed daily with tropical fish food flakes. In addition to rearing tadpoles in Glasgow from egg clutches freshly collected in Trinidad, we reared egg clutches at Manchester Museum (University of Manchester, England), produced by adults maintained there in vivaria for several years and originally derived from egg clutches brought from Trinidad as part of a program designed to assess captive breeding techniques.

Once tadpoles completed metamorphosis, the young frogs were maintained in glass vivaria each containing a large bowl of shallow water at the bottom and potted plants such as Spathiphyllum sp. and Monstera deliciosa Liebm. that provided refuges, perches and branches for climbing. Lighting (T5 6\% UVB) was provided on a 12:12 hour cycle; temperature was maintained in the range $23-27^{\circ} \mathrm{C}$ and ambient humidity was kept above $60 \%$ by misting with water once a day in the evening. Appropriately sized live food-crickets: Acheta domesticus (Linnaeus, 1758)—was provided up to four times a week for young frogs, reducing to three times as growth slowed around adult size. Crickets were maintained on a diet of fresh vegetables and supplemented with vitamin and mineral supplement 'Repashy calcium plus' prior to feeding to frogs. Vivarium size was gradually increased as frogs grew. Our general method has proved successful in rearing other hylid frogs in captivity (Bland 2013). Under these conditions, some $P$. trinitatis reached adult size, capable of breeding, in as little as 12 months.

\section{Examination of Phyllomedusa Specimens Held} by the Natural History Museum (NHM), London

We examined the ventral patterns of seven Phyllomedusa species and two species formerly classified as Phyllomedusa (but now assigned to different genera within the family Phyllomedusidae: see Table 1) held in the NHM spirit collection (originally fixed in formalin and later transferred to ethanol). Ventral patterns were photographed using a phone camera. Literature searches were used to add ventral descriptions for species of Phyllomedusa not available to us as museum specimens.

\section{Results}

Phyllomedusa trinitatis: Field Observations and Ventral Pattern Description

In 2015, 53 frogs (4 females, 49 males) were recorded at Simla. Of these, the ventral markings allowed 34 to be identified as frogs seen on at least one previous occasion that year, and five to be identified as frogs seen in 2014, when 23 different frogs were recorded. Figure 1 shows the ventral pattern of a frog captured in both 2014 and 2015. In 2016, 61 frogs (16 females, 45 males) were recorded. Four of the males present in 2016 had been recorded in 2015. None of the 2014 frogs were seen in 2016. Size measurements never contradicted the visual pattern identifications.

Typically, the ventral markings consist of (a) a large irregular, variably-sized white 'island', often outlined in black/brown and often showing a green central area. The island is situated in the ventral midline at the level of the forearms. There are also (b) a variable number of irregularly spaced white dots, often outlined in black/brown and situated anterior or posterior to the island. The island is occasionally sub-divided into two, and the positions of both islands and dots are variable (Figures 1-3). In 37 out of 58 uniquely identifiable frogs examined in 2016 and 2017, the island showed some green coloration; 39 $(67 \%)$ of the identified individuals showed dots as well as islands, ranging in number from 1-9 dots (mean $3.1 \pm 0.4 \mathrm{SE}$ ). Although we captured fewer females than males, there was no evidence of sexual dimorphism in the occurrence and diversity of the ventral patterns as described 
above. We found no frog that lacked a pattern of this general kind.

Figure 2 shows photographs of the ventral patterns of ten frogs captured over six nights at the Valencia-Matura roadside ditch site in 2006. Careful examination of these images shows that only six different frogs were captured, with one (Figure 2B, D, F, G, J) caught five times in total, with 52 days between the first and final capture. In the recorded images, pattern details may be partially obscured by limbs, but visual examination confirmed identity.

\section{Ventral Pattern Development and Stability}

In all seven frogs reared and assessed for their ventral patterns at Manchester Museum from early post-metamorphic juveniles to adulthood, the ventral pattern was distinctive and individual in each case and remained recogni- zably the same, except that in one frog, the shape of the island changed slightly, though the pattern of spots remained identical (Figure 3A, B). Nine frogs reared and assessed in Glasgow from spawn collected in Trinidad gave the same basic result; the ventral patterns were variable between individuals and the pattern on each individual remained stable as the frogs grew with only slight changes in the shape of the 'islands' (Figure 3C-F).

\section{Museum Specimens}

Of the 16 species currently recognized as belonging to the genus Phyllomedusa (Frost 2018), species descriptions (and examinations of museum specimens) for 13 of these (Table 1) suggest that they would be suitable for individual identification using photographs of chin and ventral patterning.
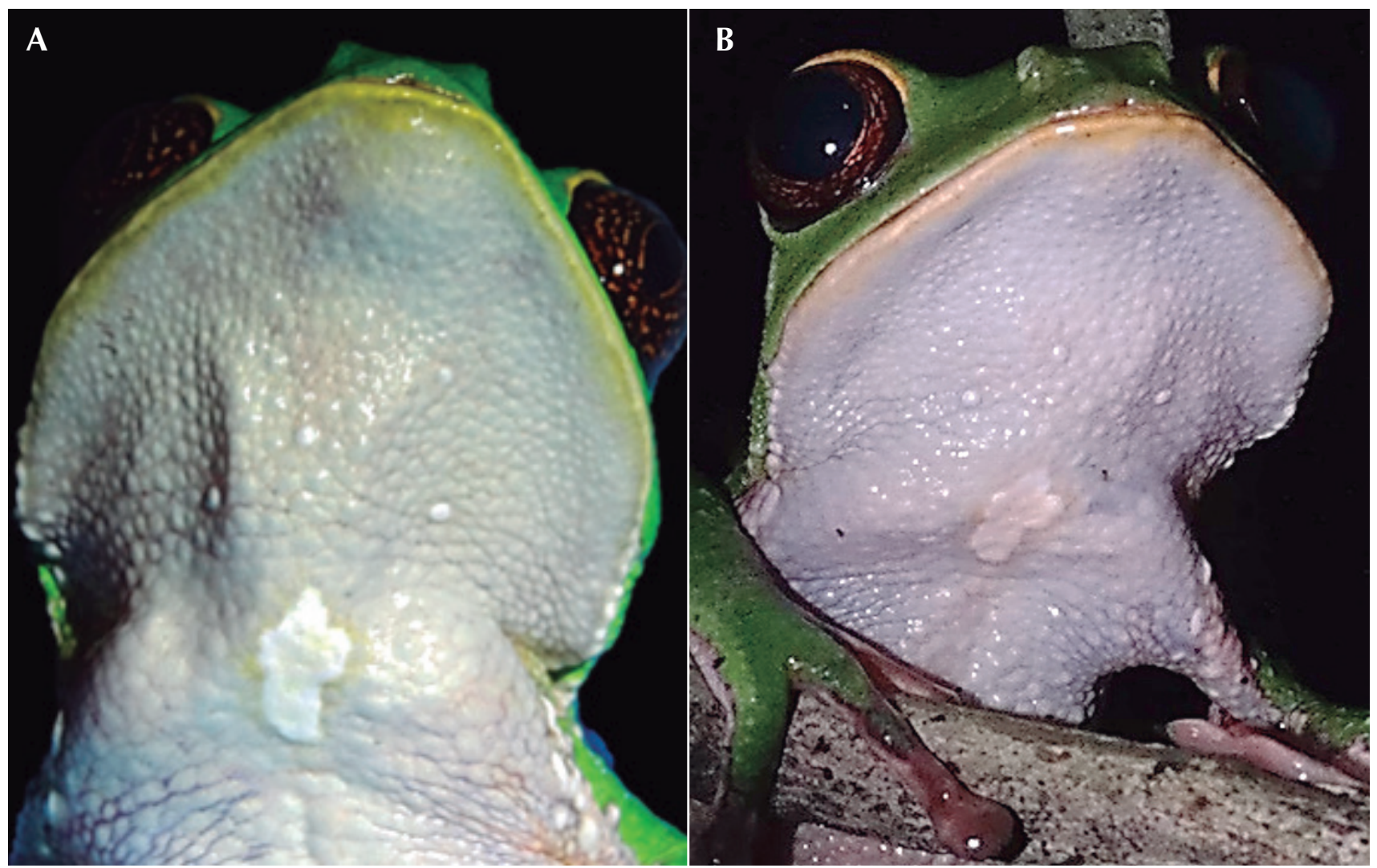

Figure 1. Ventral patterns on the same frog captured one year apart at William Beebe Research Station in the Arima Valley: (A) 03 July 2014, (B) 22 June 2015. 
Smith et al.

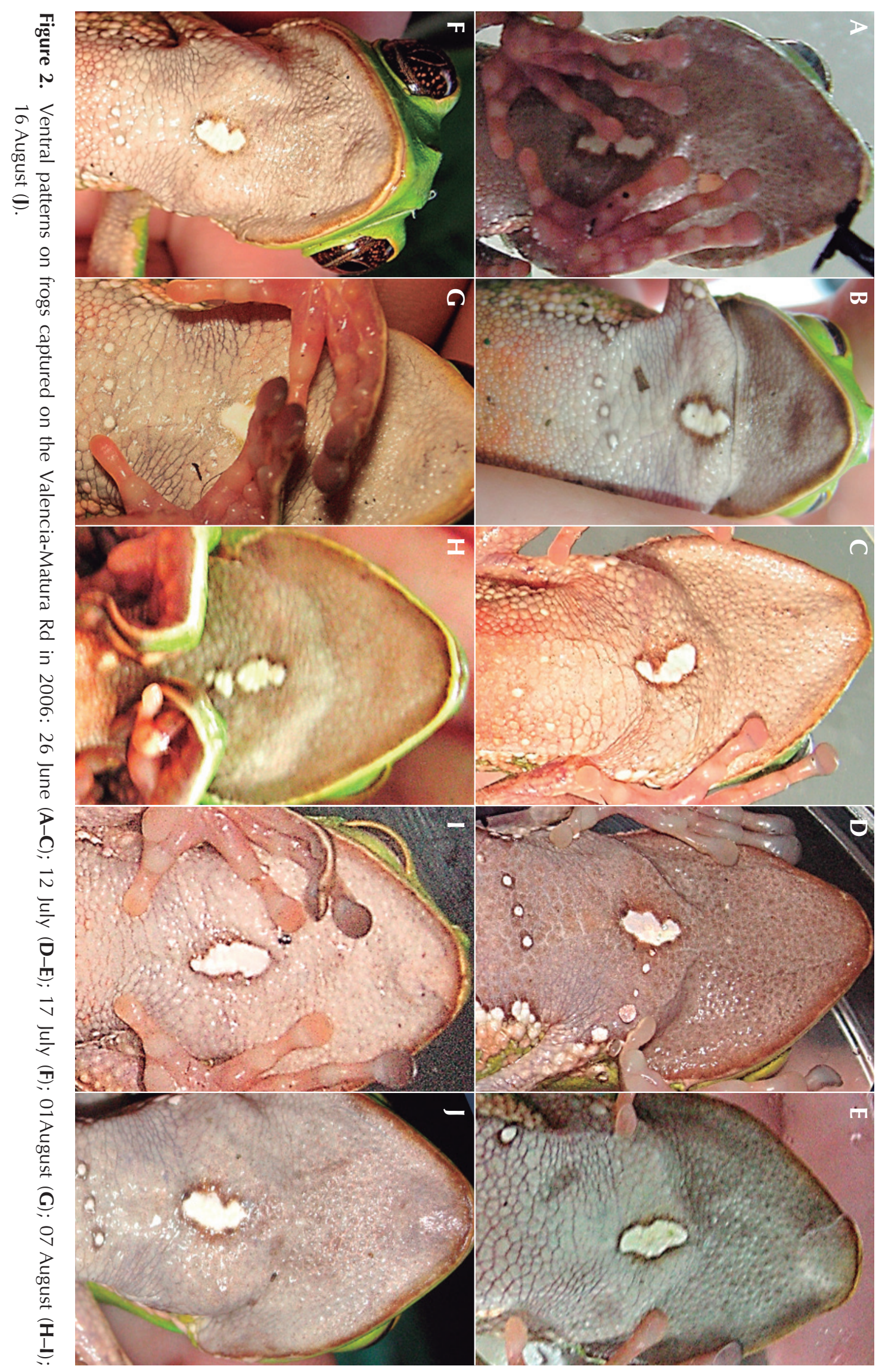


Results from our examination of seven Phyllomedusa, one Pithecopus and one Agalychnis species in the NHM are shown in Table 1 and Figure 4. Table 1 also shows data taken from published accounts of species not available in the NHM. Ventral patterns appear well preserved even in specimens well over 100 years old. Accession numbers, including collection years and locations of the specimens examined are given in Appendix I. The patterns found in $P$. coelestis (Cope, 1874), P. tarsius (Cope, 1868), and $P$. vaillanti Boulenger, 1882 were quite
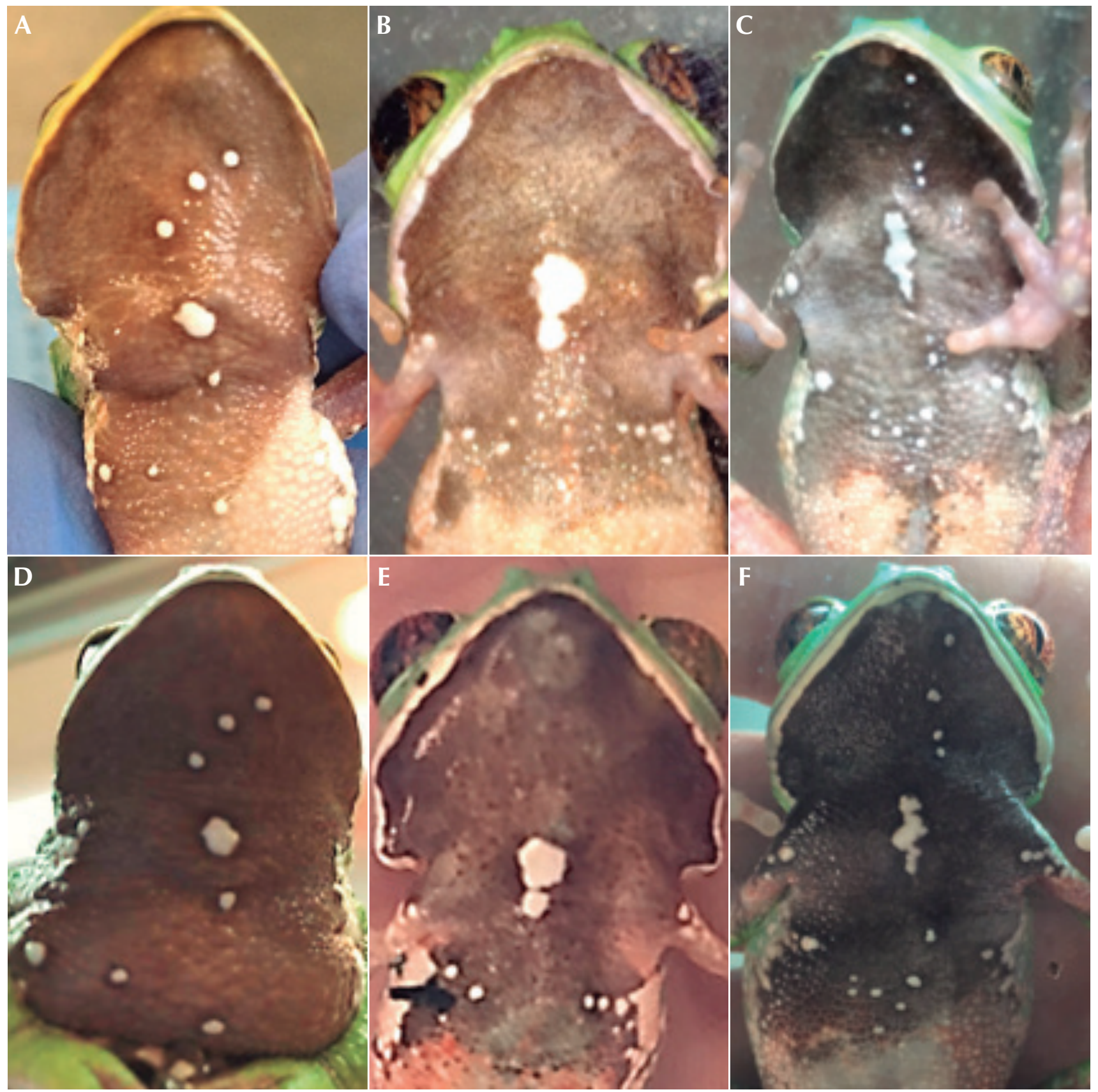

Figure 3. Photographs of the ventral surface of three $P$. trinitatis raised from metamorphosis to adulthood at Manchester Museum and the University of Strathclyde. (A-C): Juvenile frogs (40-60 mm SVL), between a month and four months from metamorphosis. (D-F): Correspond to the same frogs as adults, between 18-21 months old (about $80 \mathrm{~mm} \mathrm{SVL)}$. 
A
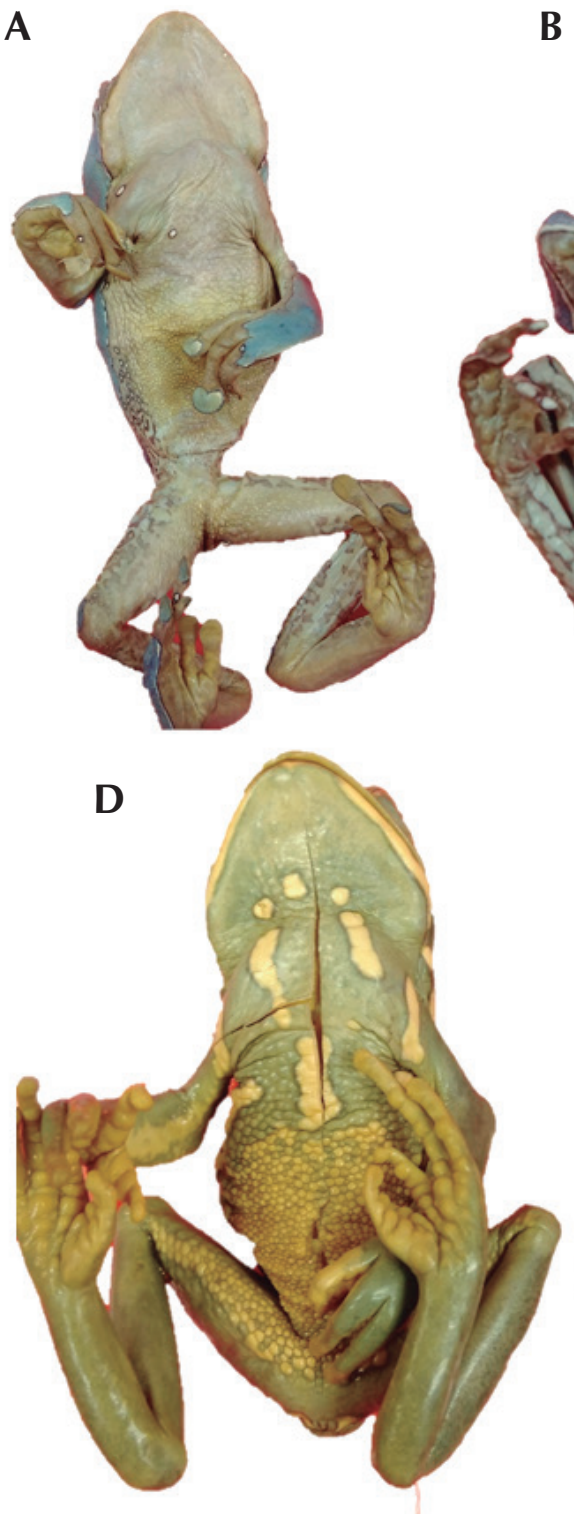

B
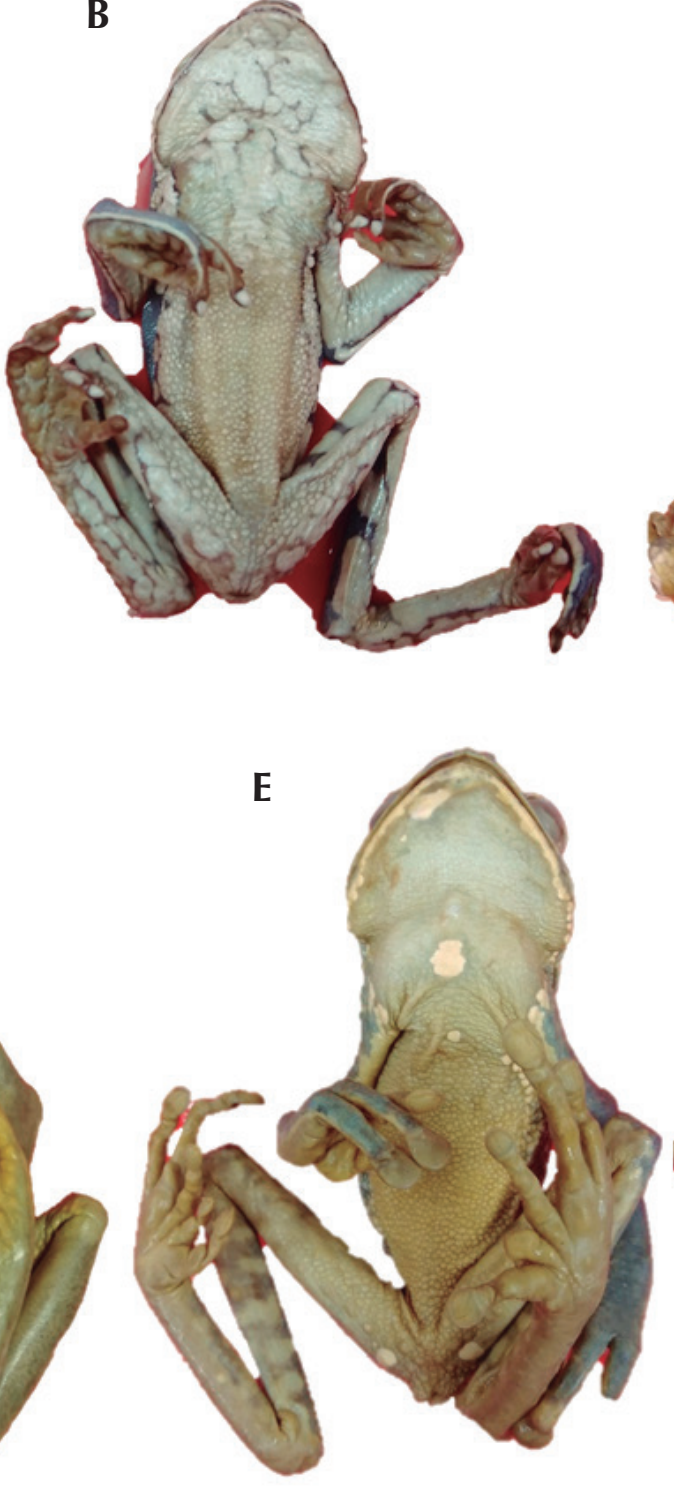

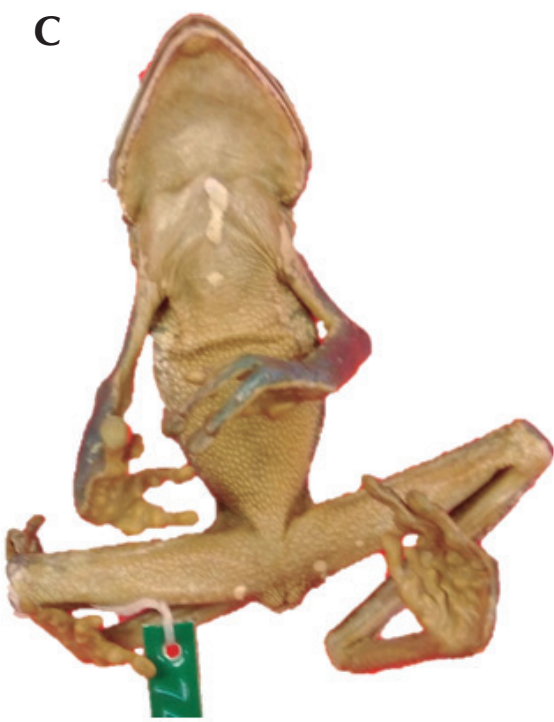

$\mathbf{F}$

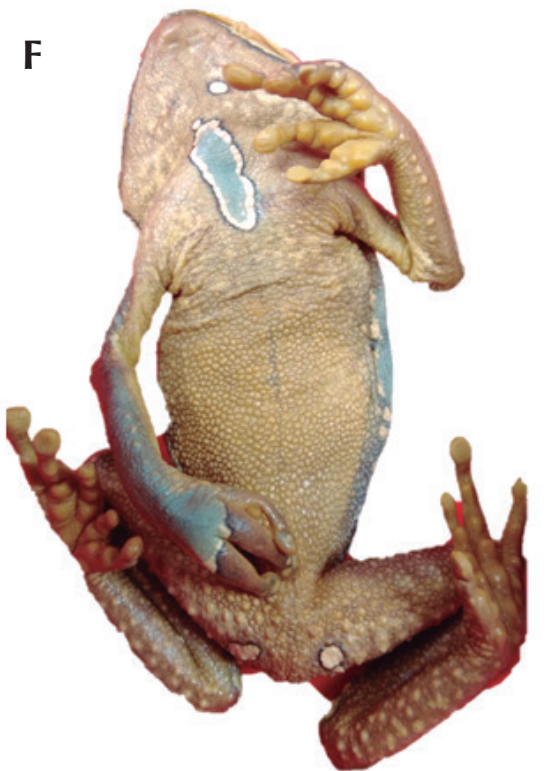

Figure 4. Photographs of Phyllomedusa species ventral surfaces, taken at the Natural History Museum $(P$. trinitatis not shown). Accession year in brackets when known. (A) P. bicolor (1872), (B) P. burmeisteri (1887), (C) $P$. coelestis (1874), (D) P. sauvagi (1904), (E) P. tarsius (XIX century), (F) P.vaillanti (1904).

similar to each other and to our findings in $P$. trinitatis. Most of the seven P. burmeisteri Boulenger, 1882 specimens lacked the trinitatistype pattern, but one had it. Phyllomedusa bicolor (Boddaert, 1772) lacked islands, but had a variable pattern of spots, while $P$. sauvagii Boulenger, 1882 had a more complex pattern of islands and spots. The Pithecopus species we examined, formerly Phyllomedusa hypochondrialis Group, lacked a ventral spot or island pattern, as did Agalychnis dacnicolor, although the latter had variable dorsal spots.

\section{Discussion}

Methods that are capable of identifying individual animals are vital for a wide range of studies in behavior and ecology. In frogs, the most commonly used method has been toeclipping, but this is contentious because of its 
Table 1. Ventral patterns in 16 species of Phyllomedusa, Pithecopus hypochondrialis, and Agalychnis dacnicolor. Those indicated in bold were examined as specimens in the NHM (JRD), other descriptions from literature.

\begin{tabular}{|c|c|c|}
\hline Species & Description of ventral pattern & Spots? \\
\hline Phyllomedusa bahiana & $\begin{array}{l}\text { Indistinguishable as adults from P. burmeisteri other than differences in } \\
\text { colouration of inside of thigh (Silva-Filho and Juncá 2006) }\end{array}$ & Yes \\
\hline Phyllomedusa bicolor & $\begin{array}{c}\text { No ventral islands, but a very variable number and distribution of white } \\
\text { spots outlined in black, mainly between the fore-arms (NHM, } \\
6 \text { specimens, see Appendix I) }\end{array}$ & Yes \\
\hline Phyllomedusa boliviana & $\begin{array}{c}\text { "Ventral surface of chin pale brown, with few diffuse cream spots" } \\
\text { (Cannatella 1983) }\end{array}$ & Yes \\
\hline Phyllomedusa burmeisteri & $\begin{array}{l}\text { Anterior ventral surface variably mottled brown/cream; most specimens lack } \\
\text { distinct spots, but one has them (NHM, } 7 \text { specimens, see Appendix I) }\end{array}$ & $\mathrm{Yes} / \mathrm{No}$ \\
\hline Phyllomedusa camba & $\begin{array}{l}\text { "Throat...grayish-cream to pale brown: an elongate, irregular white spot } \\
\text { is always present at point level near the insertion of the upper arms. Other } \\
\text { similar spots may be present... extending onto the chest" (De la Riva 1999) }\end{array}$ & Yes \\
\hline Phyllomedusa chapparoi & $\begin{array}{c}\text { "Morphologically indistinguishable" from P. camba" (above) } \\
\text { (Castroviejo-Fisher et al. 2017) }\end{array}$ & Yes \\
\hline Phyllomedusa coelestis & $\begin{array}{l}\text { Variable. Single island midway between forearms; cream/white sometimes } \\
\text { with a brown outline; additional white spots on chin or posterior to island } \\
\qquad \text { (NHM, } 3 \text { specimens, see Appendix I). }\end{array}$ & Yes \\
\hline Phyllomedusa distincta & $\begin{array}{l}\text { Yellow ventral surface - suffused blotches on white background } \\
\text { (photo in Bertoluci 2005) }\end{array}$ & No \\
\hline Phyllomedusa iheringii & Creamy-yellow to white ventral surface (photo in Borteiro et al. 2014) & No \\
\hline Phyllomedusa neildi & $\begin{array}{c}\text { "Belly and ventral surfaces of limbs yellowish brown; irregular white spot, } \\
\text { approximately at juncture of each forelimb, in some individuals extending } \\
\text { from anterior part of chest to posterior part of throat, bordered or not by } \\
\text { smaller white spots" (Barrio-Amorós 2006) }\end{array}$ & Yes \\
\hline Phyllomedusa sauvagii & $\begin{array}{l}\text { Ventral surface anterior to forearms greenish; posterior cream and covered in } \\
\text { small tubercles. On the green surface, a complex variable pattern of multiple } \\
\text { islands, often interconnecting, plus spots; islands have dark outlines and } \\
\text { white/cream interiors (NHM, } 10 \text { specimens, see Appendix I) }\end{array}$ & Yes \\
\hline Phyllomedusa tarsius & $\begin{array}{l}\text { Very variable. Typically, a white/cream island, sometimes with a dark } \\
\text { border, located mid-way between the fore-arms. Variable number of } \\
\text { white spots on the chin (NHM, } 16 \text { specimens, see Appendix I) }\end{array}$ & Yes \\
\hline Phyllomedusa tetraploidea & Uniform white venter (Photo in Dias et al. 2013) & No \\
\hline Phyllomedusa trinitatis & $\begin{array}{l}\text { Specimens in poor condition, but ventral pattern similar to that reported } \\
\text { from live specimens (NHM, } 2 \text { specimens, see Appendix I) }\end{array}$ & Yes \\
\hline Phyllomedusa vaillanti & $\begin{array}{l}\text { Mid-way between the fore-arms a variably shaped island, outlined in black; } \\
\text { interior first cream/white then a center of green. On chin, two more or less } \\
\text { circular white spots, outlined in black (NHM, } 7 \text { specimens, see Appendix I) }\end{array}$ & Yes \\
\hline Phyllomedusa venusta & "Chin and chest dark brown with white median spot" (Duellman 1970) & Yes/No \\
\hline $\begin{array}{l}\text { Pithecopus } \\
\text { hypochondrialis }\end{array}$ & No ventral spots or islands (NHM, 15 specimens, see Appendix I) & No \\
\hline Agalychnis dacnicolor & $\begin{array}{l}\text { No ventral spots or islands, but does have variable dorsal spots } \\
\text { (NHM, } 10 \text { specimens, see Appendix I) }\end{array}$ & No \\
\hline
\end{tabular}


harmful effects (May 2004, Parris et al. 2010). Here, we demonstrate that in Phyllomedusa trinitatis a variable ventral pattern of 'islands' and spots is ontogenetically stable, and can be used through digital photography to recognize individuals. The variable number and spacing of the spots, found in two thirds of individuals, is especially helpful in the recognition process. The method's use involves only gentle handling, which is essentially non-invasive, particularly considering the placid nature of these frogs, which do not struggle to escape. Kenny (1969) noted that these frogs have a 'white diamondshaped blotch' on the chest, and Murphy (1997) mentioned white spots, but neither author drew attention to the individual variation in this feature.

We have used this method successfully to follow the territoriality and breeding pool attendance patterns of a population of more than 60 frogs (E. Gourevitch, pers. comm.) and to test the efficacy and safety of two kinds of tracking device (Gourevitch and Downie 2018). We also provide preliminary evidence that similar patterns may be usable in other Phyllomedusa species and that they survive long-term preservation. The evidence is preliminary because we have not assessed ontogenetic stability in species we evaluated from museum specimens.

The patterns we have observed are distinct and variable enough to indicate that they may have a recognition function for the frogs themselves. Although it seems counter-intuitive to expect nocturnal frogs to employ visual signals in addition to the auditory signals emitted by most species, there is increasing evidence for such visual signaling (Hodl and Amézquita 2001). In the family Phyllomedusidae, Pyburn (1970) described how males lift and extend their bodies, making them more detectible and recognizable, when calling from branches. The calls tend to be brief, sporadic and soft, and Jacobs et al. (2016) found that most females locate and choose their mates in the absence of calls, suggesting that visual signaling is in operation. Most emphasis has been placed on limb movements and flank striping patterns as the sources of such signals (Robertson and Greene 2017), but the elevation of the body and head makes it plausible that throat underside patterns could be used too.

In another member of the family Phyllomedusidae, De Oliveira et al. (2012) reported on territoriality in Pithecopus megacephala (Miranda-Ribeiro, 1926) (formerly Phyllomedusa) in Brazil. They used two marking techniques: first, they photographed the right flank, including the upper leg, of each individual; this area has a pattern of irregular dark stripes against a pale background. However, to verify that this pattern allowed reliable recognition of individuals, they also used toe-clipping of up to two toes per foot (but not hands). They concluded that the photographic procedure 'proved to be very effective for distinguishing each individual, and did not seem to cause any physical harm or stress or interfere with individual fitness,' but they did not actually present any evidence to this effect, nor did they comment on the effects of toe-clipping in this species. In our original (2006) efforts to identify individual $P$. trinitatis, we examined and photographed lateral striping patterns as well as ventral throat markings. We found the lateral markings to be individually variable but more complex and difficult to compare than the throat markings.

Kenyon et al. (2009) compared photographic identification with toe-clipping in the tree frog Ranoidea genimaculata (Horst, 1883) (= Litoria genimaculata). They found that the photographic method was much less reliable and took significantly more time. In this species, the occurrence of a distinctive dorsal hourglass pattern was variable, and dorsal patterns were altered over time in individuals, both contributing to the relative unreliability of the photographic method. Del Lama et al. (2011) compared photoidentification with examination of live animals in the tree frog Ololygon longilinea (Lutz, 1968) (= Scinax longilineus), using the variable blotch patterns on the flanks. They reported a high 
recognition success rate, but noted that both physiological color change and ontogenetic pattern changes can cause problems with identification. Their method also required substantial manipulation of the frogs in order to expose the relevant body parts. Elgue et al. (2014) reported somewhat similar results to ours: they found individually variable ventral blotch patterns, stable over 16 months, in adult Uruguayan toads-Melanophryniscus montevidensis (Philippi, 1902). Elgue et al. (2014) used Wild-ID (Bolger et al. 2012: an open access free software package) to identify individuals. This required manipulation of the original images and visual checking to confirm identifications. The method was successfully used for over 400 toads as part of a markrecapture study. It was more time-consuming than our method, but the toads' belly patterns were complex and our method would have been inappropriate, especially on a large population. Renet et al. (2019) compared Wild-ID and AMPHIS as computer-based image analysis systems for distinguishing individual salamanders, using complex ventral patterns. Success rate was very high, but, in our view, the manipulations required to obtain adequate photographs were not compatible with behavioral studies. Wild-ID could be used on Phyllomedusa, but was not available when we first used throat patterns as an identification aid. We feel that visual identification remains a viable qualitative method when the patterns used are fairly simple, sample sizes are small, and when frequent identification is needed, as in behavioral studies, when stressful and time-consuming handling should be minimized. It will also remain viable for field studies where the technology available is limited.

We expect that more species of frogs will turn out to have individual patterns that can be used for recognition. However, we feel that it is important that a full evaluation is carried out, including ontogenetic stability. Meanwhile, the patterns we have described should be valuable for studies on other Phyllomedusa species.

\section{Acknowledgments}

Adam Bland reared and measured some of the Phyllomedusa specimens reported here while based at The Manchester Museum. We thank Jeff Streicher for information on and access to the NHM amphibian collections and Naomi Barron for taking the photographs there. We acknowledge the helpful comments made by two anonymous referees. Joanna Smith, Eleanor Gourevitch and Roger Downie's contributions to this paper derive mainly from fieldwork carried out in Trinidad during University of Glasgow expeditions, funded by many agencies, principally the University of Glasgow's Chancellor's Fund, Glasgow Natural History Society, the Thriplow Trust, the Gilchrist Educational Trust and Dennis Curry's Charity. Fieldwork and specimen export permissions were granted by the Wildlife Section of the Trinidad Government's Forestry Division (Special Game Licenses 2014-16; Wildlife Special Export License 001741, 2014).

\section{References}

Arntzen, J. W., I. B. J. Goudie, J. Halley, and R. Jehle. 2004. Cost comparison of marking techniques in long-term population studies: PIT-tags versus pattern maps. Amphibia-Reptilia 25: 305-315.

Arntzen, J. W. and S. F. M. Teunis. 1993. A six year study on the population dynamics of the crested newt (Triturus cristatus) following the colonization of a newly created pond. Herpetological Journal 3: 99-110.

Bainbridge, L., M. Stockwell, J. Valdez, K. Klop-Toker, S. Clulow, J. Clulow, and M. Mahony. 2015. Tagging tadpoles: retention rates and impacts of visible implant elastomer (VIE) tags from the larval to adult amphibian stages. Herpetological Journal 25: 133-140.

Barrio-Amorós, C. L. 2006. A new species of Phyllomedusa (Anura: Hylidae: Phyllomedusinae) from northwestern Venezuela. Zootaxa 1309: 55-68.

Bertoluci, J. 2005. Phyllomedusa distincta: la rana hoja de São Paulo. Reptilia 56: 70-74.

BHS (British Herpetological Society). 2017. British Herpetological Society: ethical policy and guidelines. British Herpetological Bulletin 141: 46-48. 
Bland, A. 2013. The husbandry and captive reproduction of the gliding leaf frog Agalychnis spurrelli (Boulenger, 1913). Herpetological Bulletin 124: 9-12.

Bolger, D. T., T. A. Morrison, B. Vance, D. Lee, and H. Farid. 2012. A computer-assisted system for photographic mark-recapture analysis. Methods in Ecology and Evolution 3: 813-822.

Borteiro, C., D. Baldo, T. S. Kunz, R. Perez, R. P. Eltz, F. Kolenc. 2014. Contracting behaviour in three species of Phyllomedusa (Anura: Hylidae: Phyllomedusinae). Herpetology Notes 7: 393-395.

Brannelly, L. A., M. W. H. Chatfield, and C. L. RichardsZawacki. 2013. Visual implant elastomer (VIE) tags are an unreliable method of identification in adult anurans. Herpetological Journal 23: 125-129.

Brannelly, L. A., L. Berger, and L. F. Skerratt. 2014. Comparison of three widely used marking techniques for adult anuran species Litoria verreauxii alpina. Herpetological Conservation and Biology 9: 428-435.

Cannatella, D. C. 1983. Synonymy and distribution of Phyllomedusa boliviana Boulenger (Anura: Hylidae). Proceedings of the Biological Society of Washington 96: 59-66.

Castroviejo-Fisher, S., J. Köhler, I. De la Riva, and J. M. Padial. 2017. A new morphologically cryptic species of Phyllomedusa (Anura: Phyllomedusidae) from Amazonian forests of northern Peru revealed by DNA sequences. Zootaxa 4269: 245-264.

Davis T. M. and K. Ovaska. 2001. Individual recognition of amphibians: effects of toe clipping and fluorescent tagging on the salamander Plethodon vehiculum. Journal of Herpetology 35: 217-225.

Del Lama, F., M. D. Rocha, M. A. Andrade, and L. B. Nascimento. 2011. The use of photography to identify individual tree frogs by their natural marks. South American Journal of Herpetology 6: 198-204.

De la Riva, I 1999. A new Phyllomedusa from southwestern Amazonia (Amphibia: Anura: Hylidae). Revista Española de Herpetología 13: 123-131.

De Oliveira, F. F. R., P. A. G. Nogueira, and P. C. Eterovick. 2012. Natural history of Phyllomedusa megacephala (Miranda-Ribeiro, 1926) (Anura: Hylidae) in southeastern Brazil, with descriptions of its breeding biology and male territorial behaviour. Journal of Natural History 46: 117-129.

Dias, T. M., F. P. Maragno, B. Madalozzo, C. P. A. Prado, S. Z. Cechin. 2013. Breeding sites of the leaf frog Phyllomedusa tetraploidea (Hylidae, Phyllomedusinae) in a forest remnant in southern Brazil. North-Western Journal of Zoology 9: 422-424.
Downie, J. R., M. Nokhbatolfoghahai, D. Bruce, J. M. Smith, N. Orthmann-Brask, and I. MacDonald-Allan. 2013. Nest structure, incubation and hatching in the Trinidadian leaf-frog Phyllomedusa trinitatis (Anura: Hylidae). Phyllomedusa 12: 13-32.

Duellman W. E. 1970. The hylid frogs of Middle America. Monograph of the Museum of Natural History, University of Kansas 1: 1-753 pp.

Duellman, W. E., A. B. Marion, and S. B. Hedges. 2016. Phylogenetics, classification, and biogeography of the treefrogs (Amphibia: Anura: Arboranae). Zootaxa 4104: 1-109.

Elgue, E., G. Pereira, F. Achaval-Coppes, and R. Maneyro. 2014. Validity of photo-identification technique to analyse natural markings in Melanophryniscus montevidensis (Anura: Bufonidae). Phyllomedusa 13: 59-66.

Ferner, J. W. 2010. Measuring and marking postmetamorphic amphibians. Pp. 123-141 in C. K. Dodd Jr. (ed.), Amphibian Ecology and Conservation: a Handbook of Techniques. Oxford. Oxford University Press.

Fisher, K. J., K. J. Guilfoyle, and K. A. Hatch. 2013. Stress induced by toe-clipping in Cane Toads (Rhinella marina). Copeia 2013: 539-542.

Frost, D. R. (ed.). 2018. Amphibian Species of the World: an Online Reference. Version 6.0 (13 November 2018). Eletronic Database accessible at http://research.amnh. org/herpetology/amphibia/American Museumof Natural History, New York, USA. Captured on 20 November 2018.

Gourevitch, E. H. Z. and J. R. Downie. 2018. Evaluation of tree frog tracking methods using Phyllomedusa trinitatis (Anura: Phyllomedusidae). Phyllomedusa 17: 233-246.

Grafe, T. U., M. M. Stewart, K. P. Lampert, and M.-O. Rödel. 2011. Putting toe clipping into perspective: a viable method for marking anurans. Journal of Herpetology 45: 28-35.

Hagström, T. 1973. Identification of newt specimens (Urodela, Triturus) by recording the belly pattern and a description of photographic equipment for such registrations. British Journal of Herpetology 4: 321326.

Heard G. W., M. P. Scroggie, and B. M. Malone. 2008. Visible implant alphanumeric tags as an alternative to toe-clipping for marking amphibians-a case study. Wildlife Research 35: 747-759.

Hodl, W. and A. Amézquita. 2001. Visual signalling in anuran amphibians. Pp. 121-141 in M. J. Ryan (ed.), Anuran Communication. Washington. Smithsonian Institution Press. 
Jacobs, L., A. Vega, S. Dudgeon, K. Kaiser, and J. M. Robertson. 2016. Local not vocal: assortative female choice in divergent populations of red-eyed tree frogs Agalychnis callidryas (Hylidae: Phyllomedusinae). Biological Journal of the Linnean Society 120: 171-178.

Kenny, J. S. 1969. The Amphibia of Trinidad. Studies on the Fauna of Curacao and Other Caribbean Islands 29: 1-78.

Kenyon, N., A. D. Phillott, and R. A. Alford. 2009. Evaluation of the photographic identification method (PIM) as a tool to identify adult Litoria genimaculata (Anura: Hylidae). Herpetological Conservation and Biology 4: 403-410.

May, R. M. 2004. Ecology: ethics and amphibians. Nature 431: 403.

McCarthy M. A. and K. M. Parris. 2004. Clarifying the effect of toe clipping on frogs with Bayesian statistics. Journal of Applied Ecology 41: 780-786.

Mettouris O., G. Megremis, and S. Giokas. 2016. A newt does not change its spots: using pattern mapping for the identification of individuals in large populations of newt species. Ecological Research 31: 483-489.

Murphy, J. C. 1997. Amphibians and Reptiles of Trinidad and Tobago. Malabar. Kreiger Publishing. 245 pp.

Narayan E. J., F. C. Molinia, C. Kindermann, J. F. Cockrem, and J.-M. Hero. 2011. Urinary corticosterone responses to capture and toe-clipping in the cane toad (Rhinella marina) indicate that toe-clipping is a stressor for amphibians. General and Comparative Endocrinology 174: $238-245$.

Parris, K. M., S. C. McCall, M. A. McCarthy, B. A. Minteer, K. Steele, S. Bekessy, and F. Medvecky. 2010. Assessing ethical trade-offs in ecological field studies. Journal of Applied Ecology 47: 227-234.
Pyburn, W. F. 1970. Breeding behavior of leaf-frogs Phyllomedusa callidryas and Phyllomedusa dacnicolor in Mexico. Copeia 1970: 209-218.

Renet, J., L. Leprêtre, J. Champagnon, and P. Lambret. 2019. Monitoring amphibian species with complex chromatophore patterns: a non-invasive approach with an evaluation of software effectiveness and reliability. Herpetological Journal 29: 13-22.

Robertson, J. M. and H. W. Greene. 2017. Bright colour patterns as social signals in nocturnal frogs. Biological Journal of the Linnean Society 121: 849-857.

Sapsford, S. J., R. A. Alford, and L. Schwarzkopf. 2015. Visible implant elastomer as a viable marking technique for common mistfrogs (Litoria rheocola). Herpetologica 71: 96-101.

Schmidt, K. and L. Schwartzkopf. 2010. Visible implant elastomer tagging and toe-clipping: effects of marking on locomotor performance of frogs and skinks. Herpetological Journal 20: 99-105.

Silva-Filho, I. S. N. and F. A. Juncá. 2006. Evidence of full species status of the neotropical leaf-frog Phyllomedusa burmeisteri bahania (A. Lutz, 1925) (Amphibia, Anura, Hylidae). Zootaxa 1113: 51-64.

Smith, J. M., T. Deas, Z. Gladman, J. Lupton, and D. McLennan. 2007. Amphibian biodiversity surveying project. Pp. 44-61 in V. Ogilvy, J. Smith, and D. Thornham (eds.), University of Glasgow Trinidad Expedition Report 2006. Glasgow. University of Glasgow Exploration Society.

Winandy L. and M. Denoël. 2011. The use of visual and automatized behavioral markers to assess methodologies: a study case on PIT-tagging in the Alpine newt. Behavior Research Methods 43: 568-576.

Editor: J. P. Lawrence 
Smith et al.

Appendix I. Specimens examined at the Natural History Museum: names as given on the specimen jars. The name hypochondrialis is now associated to the genus Pithecopus, not Phyllomedusa.

\begin{tabular}{|c|c|c|}
\hline Species & Accession details & Location \\
\hline \multirow[t]{5}{*}{ Phyllomedusa tarsius } & 1902.5 .15 .25 & Colombia \\
\hline & 1904.10.29.195-99 & Bolivia \\
\hline & $1927.8 .1 .52-3$ & Bolivia \\
\hline & 1927.8.1.54 & Bolivia \\
\hline & 1908.5.29.45 & E. Peru \\
\hline \multirow[t]{7}{*}{ Phyllomedusa sauvagi } & 1906.5.31.23 & Argentina \\
\hline & 1904.6.30.43-6 & Argentina \\
\hline & 1928.1.8.12 & Paraguay \\
\hline & 1908.5.29.29 & Argentina \\
\hline & 1898.7.7.24 & Bolivia \\
\hline & 1908.5.29.28 & Argentina \\
\hline & $1963.641-42$ & Argentina \\
\hline \multirow[t]{2}{*}{ Phyllomedusa coelestis } & 1874.8.4.94-5 & Peru \\
\hline & 1904.10.29.194 & Bolivia \\
\hline \multirow[t]{2}{*}{ Phyllomedusa trinitatis } & 1971.1629 & Trinidad \\
\hline & 1934.2.26.29 & Trinidad \\
\hline \multirow[t]{6}{*}{ Phyllomedusa burmeisteri } & 1937.7.29.45 & 'South America' \\
\hline & 1887.12.29.37.38 & Brazil \\
\hline & 1901.7.29.29.30 & Brazil \\
\hline & 1895.3.6.7 & unclear \\
\hline & 1898.5.19.4 & Brazil \\
\hline & 1926.5.5.17 & Brazil \\
\hline Phyllomedusa vaillanti & 1904.10.29.187.193 & Bolivia \\
\hline \multirow[t]{4}{*}{ Phyllomedusa bicolor } & 1872.10.16.10-11 & Demerara Falls \\
\hline & 1928.2.11.1 & Brazil \\
\hline & 1858.11.25.51 & Brazil \\
\hline & 1915.3.9.20.21 & Brazil \\
\hline \multirow[t]{6}{*}{ Pithecopus hypochondrialis } & $1972.330-331$ & Paraguay \\
\hline & $1972.322-2$ & Paraguay \\
\hline & $1972.324-28$ & Paraguay \\
\hline & $1972.320-1$ & Paraguay \\
\hline & 1972.329 & Paraguay \\
\hline & 1862.12.15.30-32 & Guyana \\
\hline \multirow[t]{7}{*}{ Agalychnis dacnicolor } & 1914.1.28.236 & Mexico \\
\hline & 1882.11.15.49-50 & Mexico \\
\hline & 1881.10.1.14 & Mexico \\
\hline & 1932.9.13.1 & Mexico \\
\hline & 1901.12.19.102-3 & Mexico \\
\hline & 1906.6.1.141 & Mexico \\
\hline & $1892.10 .31 .82-4$ & Mexico \\
\hline
\end{tabular}

